\title{
The Impact of International Trade on the Economic Development of New Hampshire State, USA
}

\author{
Adeola A. Adeniyi \\ International Business Department, Southern New Hampshire University \\ 2500 North River Road, Manchester, NH 03106
}

\begin{abstract}
International trade is an integral part of the growth of a state and globalization has made it easier for states in the United States to do business with nations outside their main spheres of influence. This study analyzes the relationship and impact of international trade on economic development in New Hampshire. Since states can easily buy from or sell products to another country, the trade has contributed to the economic growth of New Hampshire. In this study, a regression analysis was employed to evaluate data from the United States Census Bureau and other agencies from 2010 to 2019. Results show that these trade factors have a positive correlation on New Hampshire's economic development. The understanding of the behavior of these factors can provide useful information to New Hampshire government and policy makers as they seek to improve export promotion, encourage domestic investment and attract new investors to the state.
\end{abstract}

Keywords: International trade, Foreign trade, Economic growth, Economic development, Export, Import, Exchange rate

DOI: $10.7176 / \mathrm{EJBM} / 12-20-04$

Publication date:July $31^{\text {st }} 2020$

\subsection{Introduction}

Policymakers across the globe have observed international trade as one of the key factors of national economic development. According to Masumova (2019), international trade has become one of the main drivers of economic growth since the 1980s. This assertion is a feature of international trade across the globe. Most recently, international trade has become vital in the development strategy for economic growth, employment generation and poverty alleviation in any given economy (Subesingh, 2019). International trade comprises of import and export movement of goods and services, that is, the inflow and outflow of foreign exchange between a country and another. According to Wasserman \& Haltman, "International trade consists of transaction between residents of different countries". The Office of the U.S. Trade Representative (USTR) in 2018 recorded that New Hampshire was the $39^{\text {th }}$ largest state exporter of goods. The state exported a record $\$ 5.8$ billion goods to the world in 2019 and supported an estimated 19,000 jobs in 2016 (latest year available). Currently, they export a variety of their products to over 180 countries around the world. When the nation suffered recession in 2008, New Hampshire weathered it far better than some of their neighbors largely because businesses in the state sought out overseas markets to diversify their customer base, gain more orders and keep their employees working (Rose, 2014).

Over the years, it has been underscored in literature that economists have produced empirical evidence to confirm that international trade and economic growth are positively and significantly related. In addition, there have been many statistical studies to show the relationship between international trade and growth, with results that are predominantly positive and statistically significant (see Bernard \& Jensen, 1999; Wacziarg, 2001; Lewer \& Van den Berg, 2003; Irandoust, 2017). However, despite numerous literatures in international trade and growth in the economy of different countries, little has been researched on how trade and exports have impacted the economic growth of New Hampshire. To date, there is limited detailed empirical research on the impact of international trade on New Hampshire's economic development (at the state level). To fill this gap, this study seeks to conduct a search of relevant literatures and review of data from verifiable agencies to inform the public on the current relationship between international trade and economic development in New Hampshire. The study employs a regression analysis to measure how international trade impacts economic development in New Hampshire in terms of exports, imports and exchange rates. Secondary data for this study was obtained from the United States Census Bureau, United States Department of Commerce, Bureau of Economic Analysis (BEA) and Organization for Economic Co-operation and Development (OECD). The time period of study is from 2000-2019. This study seeks to analyze the relationship between international trade and Real Gross Domestic Product (RGDP) in New Hampshire and to assess the growth of international trade in the state in terms of exports and imports. As part of the significance of this current research, it is believed that this paper will help to inform the New Hampshire office of International Commerce, local and state governmental officials on the needed modifications to trade factors and interventions for international businesses. The study should form a basis to attract more foreign investors to New Hampshire and to support the expansion of businesses in the state by creating jobs, hiring more workers at home, and exporting more goods and services.

In the next section, we present a review of literature, the research methodology employed in this study, 
followed by the main findings and a discussion of results. In the final section, the concluding remarks of the study as well as the recommendations are discussed.

\subsection{Literature Review}

International trade has increased over the last hundred years, impacting the economies of many countries (James, 2014). This trade plays a critical role in determining economic growth which is represented by Gross Domestic Product (GDP) and productivity levels. International trade has become a major driver of growth in literature on economic growth and world economies are becoming more and more dependent on it (Stancheva-Gigov, 2014). The mercantilist doctrine attributed great importance to foreign trade, that is, the international exchange process of capital accumulation, a notable requirement for economic growth (Tapsin, 2016). Export services form an increasingly essential engine for international trade (Workman, 2019). This export involves the production of goods in a home country and the purchase by a foreign country (Mohan, 2005). An increase in import of raw materials, employment and production are also influenced through international trade. International trade contains efficiency and welfare achievement to all countries (Helpman,1987). This is made possible by advanced technology and improved methods of response to the changing demands of customers (Frankel \& Rose, 1998). Similarly, the exchange of knowledge, techniques and modern technology is made possible through international trade; it helps industries and businesses to increase their efficiency and productivity (Chen \& Gupta, 2006). The increase in competition has been a driver for firms to be innovative. The innovative changes especially in technologies, have led to the growth of international trade (Daumal, 2010).

There are diverse benefits of international trade to a state. First, international trade expands varieties of new products. Romer (1990) highlighted that growth in knowledge rests on the introduction of greater variety of goods and international trade plays a positive role in this connection. Rivera-Batiz \& Romer (1991) claimed that international trade in capital goods raises the market size for new product varieties. Grossman \& Helpman (1991b, 1991c)) argued that trade openness proves beneficial for the introduction of new varieties because it provides access to a wider base of technical knowledge that reduces the cost of innovation. Similarly, the innovation-based growth model of Aghion \& Howitt (1992) argued that international trade provides opportunities for innovation and consequently leads to technological improvements. Second, international trade provides access to foreign intermediate inputs. Romer (1990) argued that international trade enables countries to import intermediate inputs from abroad that are not invented domestically; this can help to foster productivity in manufacturing sector. Third, international trade facilitates the diffusion of international knowledge. Coe \& Helpman (1995) proposed that international trade in intermediate goods is the main channel of international knowledge spillovers. They supported the idea that knowledge diffused through trade seemed to raise domestic productivity and affect the economic growth of nations.

International trade, as a major factor of openness, has made an increasingly significant impact to economic growth, hence states can generate revenue through foreign trade activities (Sun \& Heshmati, 2010). Several studies address the impact of international trade on economic growth of a country and state. Kehinde et al. (2012) investigated the impact of foreign trade on economic growth using a rank correlation analysis among advanced nations. The findings of the study showed a positive relationship between international trade and economic growth. Zahoor et al. (2012) studied the relationship between international trade and economic growth using the ordinary least squares (OLS) technique and concluded that international trade is linked to the economic growth of a country. The study by Azeez et al. (2014) showed that international trade has a significant and positive impact on economic growth through imports, exports and openness on the economy.

Exchange rate has an impact on international trade. Abrams (1980) explained that the world trade has grown rapidly since the breakdown of the Bretton Woods system of fixed exchange rates in early 1973. If the domestic currency depreciates, it enhances export of the nation. Decline in the exchange rate of the domestic country will bring high foreign transactions into the country or state (Kandil et al., 2007). In the study by Bernard and Jensen (2004), they analyzed the sources of manufacturing export booms in the United States between 1987 and 1992. They found that changes in exchange rates were an important determinant of export increases. Arslan and van Wijnbergen (1993) studied the export boom of Turkey in the 1980s and assessed the relative contribution of different factors, such as export subsidies, import growth in the Middle East and exchange rate depreciation. They proposed that the steady real depreciation of the Turkish Lira played an important role in the surge in exports. Haddad and Pancaro (2010) provided further evidence of the links between real exchange rate and export expansion when their study revealed a positive association between the two variables.

In this study, the economic growth of New Hampshire is proxied by Real Gross Domestic Product (RGDP) while Export, Import and Exchange rate represent international trade. RGDP is one of the statistical indicators for the economic growth of a country or state, it is the economic output of a state without inflation. The RGDP of New Hampshire grew from $\$ 66.44$ billion in 2010 to $\$ 77.87$ billion in 2019 . In the same period, export value for the state rose from $\$ 4.37$ billion to $\$ 5.83$ billion while the import grew from $\$ 8.95$ billion to $\$ 10.52$ billion. There has been a consistent growth on all three variables - RGDP, exports and imports from 2010 through 2019, but this 
study considers the variation of import, export and exchange rate on the real GDP of the New Hampshire during these years.

\subsection{Methodology of the Study}

Research Design

Using the causal research design described by Ahamad \& Das (2018) as a cause-effect relationship, this study considers the effect of changes of one variable on another variable. The causal research design helps to assess the impact of international trade on the economic development as well as the impact of changes on existing norms. The research examines the variations in the dependent variable from the independent variables. The dependent variable is Real Gross Domestic Product (economic growth) while the independent variables are Export, Import and Real Effective Exchange.

\section{Sources of Data}

Measure data for analysis were from the United States Census Bureau, Bureau for Economic Analysis (BEA), United States Department of Commerce, Organization for Economic Co-operation and Development (OECD) and other trade agencies from year 2010 to 2019.

Model Specification

Statistical analyses were performed using a multiple regression model. This regression analysis enables the prediction of one variable based on several other variables.

The multiple regression model is $\widehat{\mathrm{RGDP}}_{\mathrm{i}}=f(\mathrm{EXR}, \mathrm{IMPR}, \mathrm{REER})$, where RGDP $=$ Real Gross Domestic Product (Dependent variable), EXR = Export for New Hampshire, IMPR = Import for New Hampshire and REER $=$ Real Effective Exchange Rate (Independent variables). The model was evaluated at a significance level of 0.10 considering the key factors of the hypothesis testing and prior studies.

$\widehat{R G D P}_{i}=\hat{\beta}_{0}+\hat{\beta}_{1} E X R+\hat{\beta}_{2} I M P R_{i}+\hat{\beta}_{3} R E E R_{i}+e_{i}$

$\mathrm{H}_{0}$ : International trade factors (Export, Import and Real Effective Exchange Rate) have no impact on Real Gross Domestic Product.

$\mathrm{H}_{1}$ : International trade factors (Export, Import and Real Effective Exchange Rate) have an impact on Real Gross Domestic Product.

\subsection{Results and Findings}

Table 1: Output of the regression analysis

Model: $\widehat{\mathrm{RGDP}}_{\mathrm{i}}=f(\mathrm{EXR}, \mathrm{IMPR}, \mathrm{REER})$

Dependent Variable: RGDP

\begin{tabular}{|lllll|}
\hline Variable & Coefficient & Std. Error & t-statistic & Prob. \\
IMPR & 0.604 & 0.216 & 1.981 & 0.095 \\
EXR & 1.583 & 0.308 & 2.323 & 0.059 \\
REER & 25.864 & 0.772 & 5.573 & 0.001 \\
\hline R-squared & 0.940 & & & \\
Adjusted R-squared & 0.910 & & & \\
Overall significance & 0.000 & & &
\end{tabular}

Source of data: U.S. Census Bureau and Organization for Economic Cooperation and Development (OECD)

Table 1 shows the output from the regression model where Real Gross Domestic Product (RGDP) is the dependent variable. All three independent variables - Import, Export and Real effective exchange rate have a positive correlation with RGDP and were statistically significant at $\mathrm{p}<0.10$. An increase in any of these variables will lead to an increase in RGDP. Also, the predicting power of the model reveals that the three independent variables used in the study can explain the variation in RGDP up to 94\%. For this model, we reject the null hypothesis since import, export and real effective exchange rate have significant impact on RGDP.

This result is consistent with previous studies that have assessed the impact of these trade determinants on economic growth. Early studies from Michaely (1977) and Balassa (1978) found that trade export volume was positively correlated with a country's economic growth. The neo-classical and classical economists argued that international trade is important in the development process of any country; it is an answer to growth. Afolabi et al. (2017) attributed the development of the world's economy to international trade and globalization, while Shihab et al. (2014) points out that the potential increase of market size and profit turnover from international trade has resulted in the growth of local industries and creation of employment opportunities for state residents. Lewer and Van de Berg (2003) concluded in their study that for every percentage point increase in the growth of international trade, the rate of economic growth defined by real GDP or per capita GDP rises. Nicit (2013) explained that the exchange rate plays an important role in a country's trade and economic performance. 
Kramer (2020) stated that both imports and exports experience growth in a healthy economy. A growing export rate indicates high level of output from the state's industries and a steady number of people employed to keep these industries in operation. Through exporting activities, there will be a higher demand for goods and services, thus an increase in production levels. This high level of production means there is flow of funds into the state, which in turn stimulates consumer spending and economic growth. Similarly, importing goods and services from abroad is said to improve the efficiency and productivity from domestic companies. A high level of import signifies a robust domestic demand and a growing economy (Surbhi, 2018).

Considering data from the United States Department of Commerce, there has been a relatively steady growth in both exports and imports for New Hampshire from the year 2010 through the year 2019 (See figure 1). The import value for New Hampshire has exceeded its exports value (trade deficit) in the last decade, yet the trade deficit has not impeded the state from being one of the productive economies in the U.S. (United States Census Bureau, 2020). Adam Smith wrote in the Wealth of Nations that a country does not become wealthy by promoting exports and discouraging imports, but through productivity.

Figure 1: International trade for New Hampshire from 2000-2019

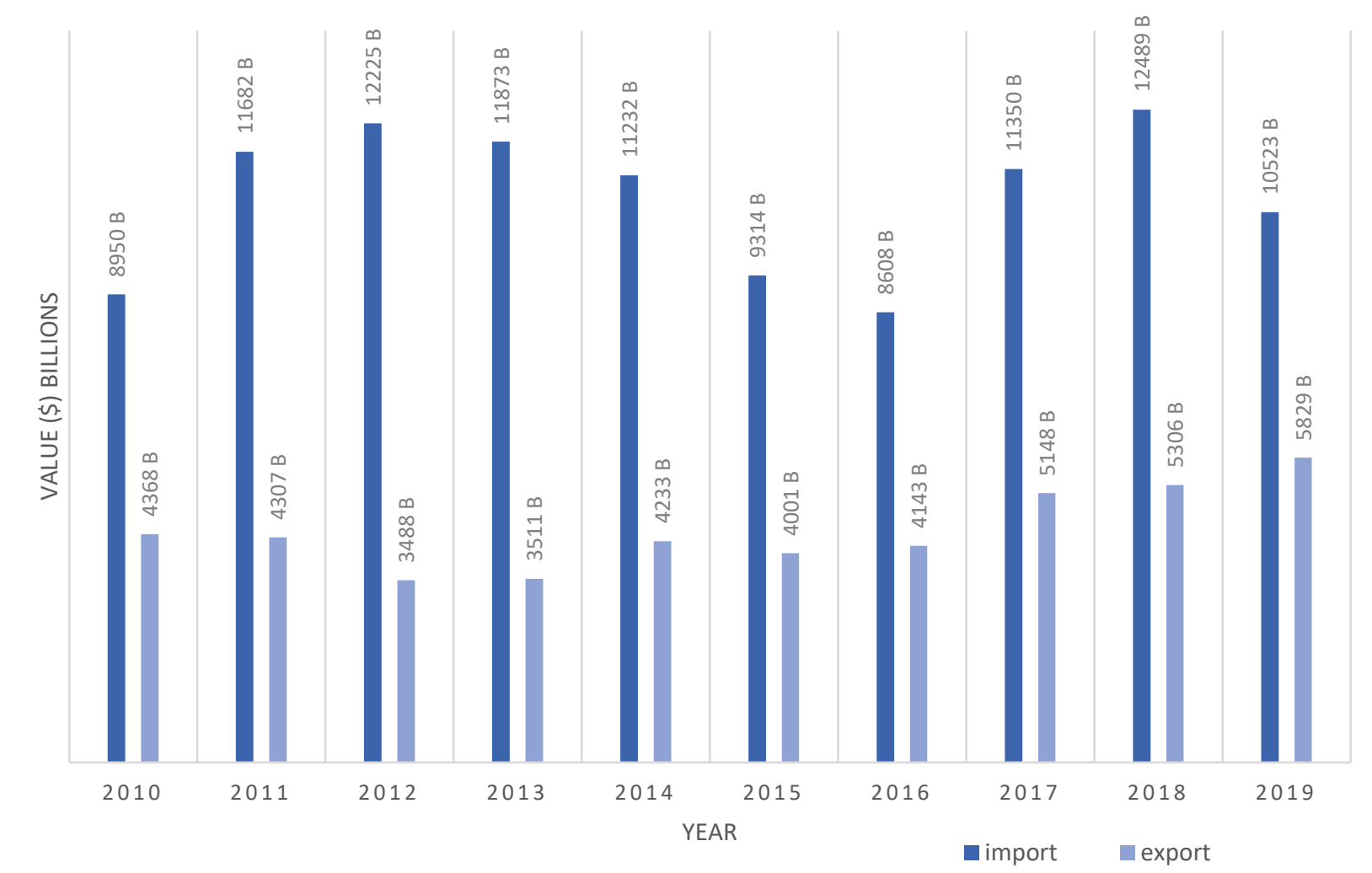

Source of Data: U.S Census Bureau, 2020

There is a consistent growth in Real GDP for New Hampshire (see Figure 2). Per the outcome from the analysis of this study and the steady growth of the Real GDP in figure 2, one can deduce that export and import contribute greatly to economic growth in New Hampshire. The growth in exports and imports indicate a sustainable foreign trade and economic strength for the state. 
Figure 2: Real GDP for New Hampshire from 2010 to 2019

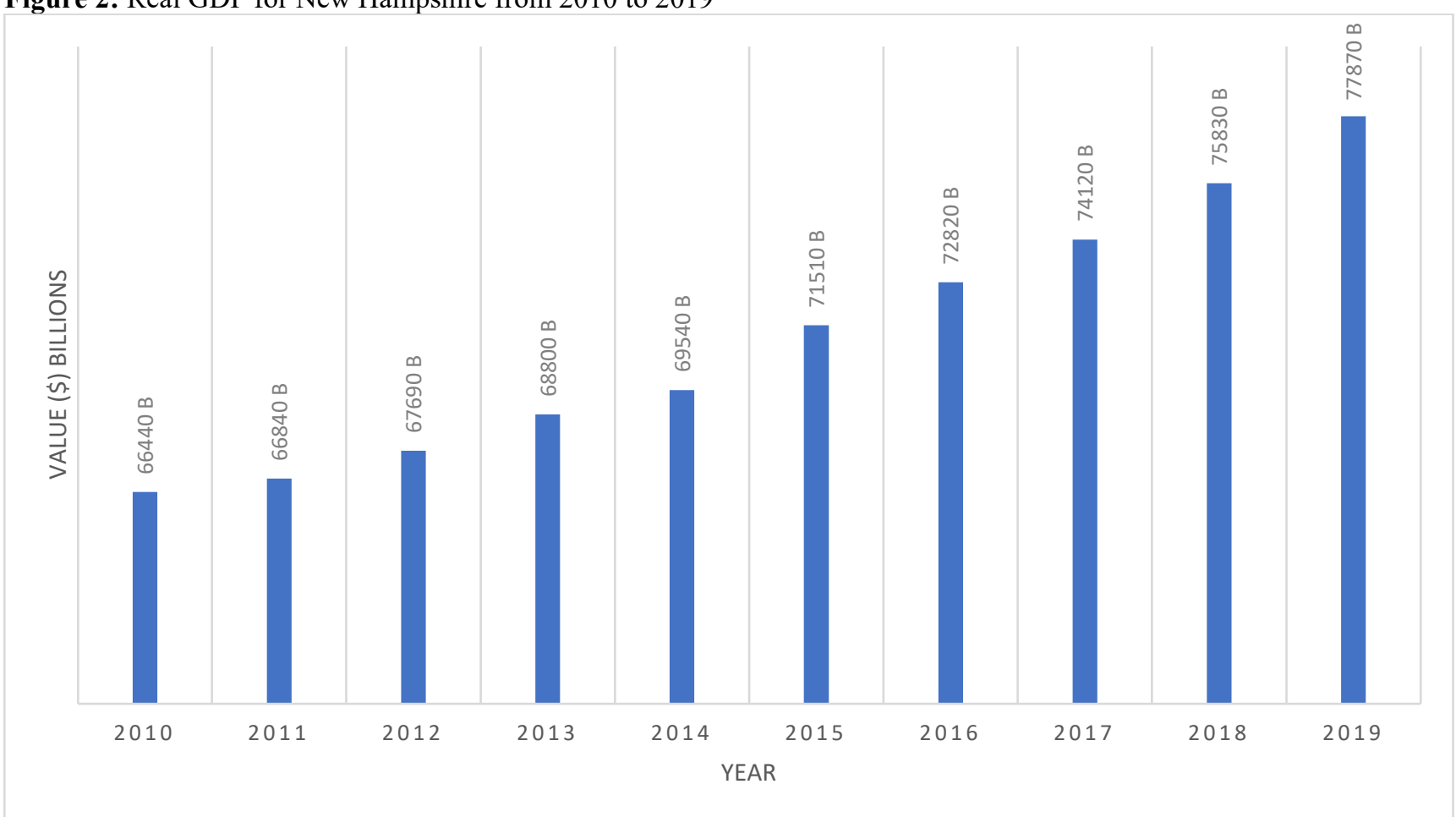

Source of Data: U.S Bureau of Economic Analysis (BEA), 2020

\subsection{Conclusion}

International trade has contributed significantly to the economic growth of New Hampshire. The growth in import and export of the state in the last decade, and a relatively stable exchange rate indicate a sustainable foreign trade and economic strength for the state. This study proposes that no state can sustain itself with its local products or trade; imports and exports are necessary for their functioning and growth. Exports and imports are economically beneficial. Exports generate huge employment opportunities while imports improve the standard of living of people in the state, especially for individual consumers. Consumers can make choices and manage their limited household budgets with products cheaply manufactured overseas than their locally produced equivalents.

Giving a better business and regulatory environment for foreign trade in New Hampshire will keep the economy of the state more open and more dynamic. Elements such as government support, infrastructure, quality of workforce, quality of life, supply chain considerations and such will attract foreign trade to the state. The foreign trade will keep inefficient monopolies in check and make the economy more competitive, thus foreign trade will expand businesses, increase employment and contribute to economic growth in the state. Policies must rely on analysis of the components of international trade in the state for continual growth in Real GDP. Government should encourage the production of more exportable commodities by the lowering of export tariffs and the giving of tax incentives and subsidies to producers when necessary. Imports reduce costs and introduces new and high-quality products to the market, therefore it should not be discounted. Exchange rate should also be stabilized towards their equilibrium level.

Though international trade contributes to economic growth and global efficiency, it may dislocation to local firms that face difficult adjustment because of the presence of foreign producers. Therefore, future studies should consider the impact of international trade on local firms and industries in New Hampshire. The study will allow the government and lawmakers to make the right trade reform policies for the state's economy.

\section{References}

Afolabi, B., Danladi, J. D., \& Azeez, M. I. (2017). International Trade and Economic Growth in Nigeria. Global Journal of Human-Social Science Research.

Aghion, P. and Howitt, P (1992). "A Model of Growth Through Creative Destruction." Econometrica, 60, 323351.

Ahamad, M. H. \& Das, B. C. (2018). Facebook Addiction among College going Students: An Exploratory Study in Patuakhali District of Bangladesh. Social Science and Humanities Journal, 617-623.

Ahamad, H. (2017). Impact of International Trade on Economic Growth in Bangladesh

Andrew, B. B. \& Bradford J. (1999). NBER WORKING PAPER SERIE EXPORTING AND PRODUCTIVITY. 
Working Paper 7135 http://www.nber.org/papers/w7 135.

Andrew, B. B. \& Bradford J. (2004). Exporting and Productivity in the USA. Oxford Review of Economic Policy, Volume 20, Issue 3, September 2004, Pages 343-357.

Azeez, B. A., Dada S. O. \& Aluko O.A. (2014). Effect of International Trade on Nigerian Economic Growth: The 21st Century Experience. Journal of Economics, Commerce and Management Vol. 11, N0. 10.

Balassa, B. (1978). "Exports and Economic Growth, Further Evidence", Journal of Development Economics, 5, pp.181-189.

Chen, P. \& Gupta R. (2006). An Investigation of Openness and Economic Growth Using Panel Estimation.

Coe, D. and Helpman, E. (1995). 'International R\&D Spillovers', European Economic Review, 1995.

Daumal, M. (2010). The impact of international trade flows on economic growth in Brazilian states. Review of Economics and Institutions, 2(1).

Frankel, J. A. \& Rose, A. K. (1998). The endogeneity of the optimum currency area criteria. The Economic Journal, 108(449), 1009-1025.

Grossman, G. M., \& Helpman, E. (1991a). Innovation and growth in the global economy. Cambridge, MA: MIT Press.

Grossman, G. M., \& Helpman, E. (1991b). Trade knowledge spillovers and growth. European Economic Review, 35, 517-526.10.1016/0014-2921(91)90153-A.

Grossman, G. M., \& Helpman, E. (1991c). Quality ladders and product cycles. The Quarterly Journal of Economics, 106, 557-586.10.2307/2937947.

Helpman, E. (1987). Imperfect competition and international trade: evidence from fourteen industrial countries. Journal of the Japanese and international economies, 1(1), 62-81.

Haddad, M. \& Pancro C. (2010). Can Real Exchange Rate Undervaluation Boost Export and Growth in Developing Countries? The World Bank, issue 20, page 1-5.

James, T. (2014). Factors influencing international trade. Access on http://www.ehow.com/info_8210281_factorsinfluencing-international-trade.html.

Lewer, J. \& Van den Beng, H. (2003). How Large Is International Trade's Effect on Economic Growth? Journal of Economic Surveys 17(3):363 - 396.

Arslan, I. \& van Wijnbergen, S. (1993). Export Incentives, Exchange Rate Policy and Export Growth in Turkey. January 1993. Review of Economics and Statistics 75(1):128-33.

Kandil, M., Berument, H., \& Dincer, N. N. (2007). The effects of exchange rate fluctuations on economic activity in Turkey. Journal of Asian Economics, 466-489.

Kehinde, A., Jubril, A., Felix, A. \& Edun, F. (2012). Foreign Trade and Economic Growth in Nigeria: An Empirical Analysis. American Academic \& Scholarly Research Journal, 4.

Kramer, L. (2020, March 20). How Importing and Exporting Impacts the Economy. Investopedia. Retrieved from https://www.investopedia.com/articles/investing/100813/interesting-facts-about-imports-and-exports.asp.

Manuchehr, I. (2017). "Estimating the Impact of Foreign Trade on GDP Growth in Sweden," World Economics, World Economics, 1 Ivory Square, Plantation Wharf, London, United Kingdom, SW11 3UE, vol. 18(3), pages 113-132, July.

Masumova, N. (2019). Foreign Trade Policy of Turkey: From Secularization to Liberalization (October 14, 2019). The World and National Economy Journal, 2019.

Michaely, M. (1977), "Exports and Economic Growth, an Empirical Investigation", Journal of development Economics, 4, pp.49-53.

Mohan, J. R. (2005) International Marketing, Oxford University Press, New Delhi and New York. ISBN 0-19567123-6

Nicit, A. (2013). Exchange Rates, International Trade and Trade Policies. Policy Issues in International Trade and Commodities Study Series No. 56, UNCTAD, Geneva.

Richard, K. A. (1980). International trade flows under flexible exchange rates. Economic review, vol. 65, issue March 3-10.

Rivera-Batiz \& Romer (1991). International trade with endogenous technological change. Economic review Vol. 35, No. 4, pp. 971-1004, (May 1991).

Rose, J. J. (2014). Trade missions: a tool for economic growth. New Hampshire Business Review, 36(12), 14

Shihab, R. A., Soufan, T., \& Abdul-Khaliq, S. (2014). The causal relationship between exports and economic growth in Jordan. Global Journal of Management and Business Research.

Stancheva-gigov, I. (2014). The Impact of Foreign Trade on Economic Growth. Journal of Sustainable Development (1857-8519). 2014;5(11):52-70.

Subesingh (2019). An Analysis of Post Liberalization Trends of Foreign Trade in India. CLEAR International Journal of Research in Commerce \& Management, 10(6), 8-11

Sun, P., \& Heshmati, A. (2010). International trade and its effects on economic growth in China

Surbhi, S. (2018). Difference Between Import and Export. Retrieved from https://keydifferences.com/difference- 
between-import-and-export.html

Tapşın, G. (2016). The Relationship between Foreign Direct Investment, Export and Economic Growth.

United States Census Bureau (2020). Foreign Trade. Available at https://www.census.gov/foreigntrade/statistics/state/data/al.html

Wacziarg, R. (2001). "Measuring the Dynamic Gains from Trade. "World Bank Economic Review15(3):393 429.

Zahoor, H. J., Qaiser I., Mushtaq A.,Ullaha S. \& Iqbal A. (2012). Effects of International Trade on Economic Growth: The Case Study of Pakistan. International Journal of Academic Research in Progressive Education and Development. Vol. 1, N0 2. 